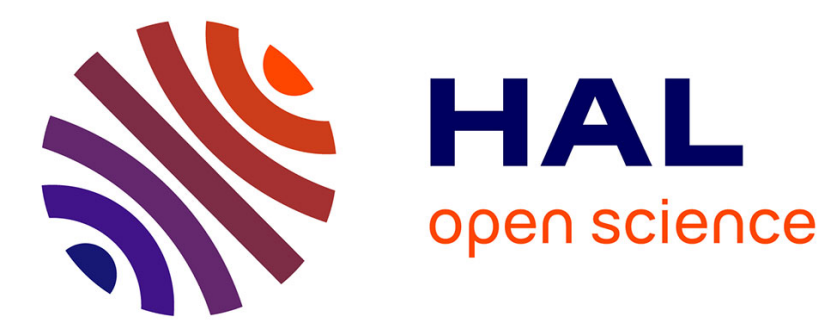

\title{
Sintering and biocompatibility of copper-doped hydroxyapatite bioceramics
}

Tiphaine Bazin, Amandine Magnaudeix, Richard Mayet, Pierre Carles, Isabelle Julien, Alain Demourgues, Manuel Gaudon, Eric Champion

\section{- To cite this version:}

Tiphaine Bazin, Amandine Magnaudeix, Richard Mayet, Pierre Carles, Isabelle Julien, et al.. Sintering and biocompatibility of copper-doped hydroxyapatite bioceramics. Ceramics International, 2021, 47 (10), pp.13644-13654. 10.1016/j.ceramint.2021.01.225 . hal-03191522

\section{HAL Id: hal-03191522 \\ https://hal.science/hal-03191522}

Submitted on 28 Apr 2021

HAL is a multi-disciplinary open access archive for the deposit and dissemination of scientific research documents, whether they are published or not. The documents may come from teaching and research institutions in France or abroad, or from public or private research centers.
L'archive ouverte pluridisciplinaire HAL, est destinée au dépôt et à la diffusion de documents scientifiques de niveau recherche, publiés ou non, émanant des établissements d'enseignement et de recherche français ou étrangers, des laboratoires publics ou privés. 


\section{Sintering and biocompatibility of copper-doped hydroxyapatite bioceramics}

Tiphaine Bazin $^{\mathrm{ab}}$, Amandine Magnaudeix ${ }^{\mathrm{a}}$, Richard Mayet ${ }^{\mathrm{a}}$, Pierre Carles $^{\mathrm{a}}$, Isabelle Julien ${ }^{\mathrm{a}}$, Alain Demourgues $^{\mathrm{b}}$ Manuel Gaudon ${ }^{\mathrm{b}}$, Eric Champion ${ }^{\mathrm{a}}$

aUniv. Limoges, CNRS, Institut de Recherche sur Les Céramiques, UMR 7315, F-87000, Limoges, France

bUniv. Bordeaux, CNRS, Institut de Chimie de La Matière Condensée de Bordeaux, UMR 5026, F-33600, Pessac, France

${ }^{*}$ Corresponding author. Université de Limoges, CNRS, SPCTS, UMR CNRS 7315, Centre Européen de la Céramique, 12 rue Atlantis, 87068, Limoges Cedex, France. eric.champion@unilim.fr

Abstract: Addition of copper in biomaterials is currently investigated because it is expected to enhance the biological properties of bone graft substitutes. Copper-doped hydroxyapatite (CuHA) ceramics were prepared by high temperature solid-state reaction sintering between $\mathrm{HA}$ and $\mathrm{CuO}$ powder mixtures. The reaction occurred from $950{ }^{\circ} \mathrm{C}$ and copper-doped apatites were obtained up to $5.3 \mathrm{wt} \%$ of copper. For higher copper content, the presence of secondary phases of $\mathrm{CuO}$ and $\mathrm{Cu}_{2} \mathrm{O}$ remained in the material. Structural analyses (XRD, FTIR) showed the substitution of hydrogen by copper into the hydroxyapatite hexagonal channels in agreement with the following chemical composition $\mathrm{Ca}_{10}\left(\mathrm{PO}_{4}\right)_{6} \mathrm{Cu}_{z}{ }_{2} \mathrm{Cu}_{\mathrm{y}}^{\prime} \mathrm{O}_{2} \mathrm{H}_{2-2 z-y}$ with $\mathrm{x}=\mathrm{y}+\mathrm{z}$ and $\mathrm{O} \leq \mathrm{x} \leq 0.7$. Dense single phased apatitic HA ceramics containing up to 5.3 wt\% of copper could be produced after natural sintering in air at $1100{ }^{\circ} \mathrm{C}$. But, copper-substituted HA was found to be metastable leading to apatitic grains and $\mathrm{Cu}$-rich grain boundaries during cooling to room temperature, which resulted in the formation of $\mathrm{CuO}$ grains at the material surface after annealing at $500^{\circ} \mathrm{C}$. Quenching from the sintering temperature was carried out to prevent this phenomenon and obtain ceramics made of single $\mathrm{Cu}-\mathrm{HA}$ phase with a homogeneous fine grain microstructure. In vitro biological assays using MC3T3-E1 cells indicated that the sintered CuHA ceramics were biocompatible, neither cell adhesion nor proliferation being affected by copper addition. A negative effect on cell differentiation appears only from 5 wt\% of copper in HA.

Keywords: Sintering ; Microstructure-final ; Apatite ; Biomedical applications

\section{Introduction}

Calcium phosphates, mainly hydroxyapatite $(\mathrm{HA})$, are of great interest for biomedical applications due to their chemical composition close to the bone. $\mathrm{HA}$, with general formula $\mathrm{Ca}_{10}\left(\mathrm{PO}_{4}\right)_{6}(\mathrm{OH})_{2}$, is a biocompatible, osteoconductive and bioactive material $[1,2]$. It has been widely used as drug delivery system, implant coating and bone substitute [[3], [4], [5]]. The bioactivity of HA allows new bone formation through biochemical bonding at the bone implant interface. In addition, the manufacturing of scaffolds with interconnected macropores (typically in the size range 300-500 $\mu \mathrm{m}$ [6] improves the implant osteointegration through its colonization by cells involved in the bone formation, vascular invasion and circulation of the nutrients. Ceramic scaffolds with large dimension may be used to replace damaged bone tissues but the cellular and vascular ingrowth hardly exceeds $1 \mathrm{~cm}$ in depth from the native bone apposition $[7,8]$. Therefore, complete osseointegration is limited. A lack of vascularization within the scaffold seems to originate the low bone ingrowth [9]. As osteogenesis is not possible without angiogenesis, the improvement of vascularization is the key point for a better osseointegration and for the development of large size HA scaffolds. 
Biological apatite is similar to a carbonate hydroxyapatite enriched with traces of various ionic species ( $\mathrm{Na}^{+}$, $\left.\mathrm{Mg}^{2+}, \mathrm{Sr}^{2+}, \mathrm{F}^{-}, \mathrm{SiO}_{4}{ }^{-} \ldots\right)$ [10]. Some of these elements play a significant role in bone mineralization process: for instance, zinc, strontium or manganese favour osteogenesis while magnesium, copper and cobalt improve angiogenesis [11]. Hydroxyapatite is known for its capacity to accept ion substitution in its lattice. Many studies have demonstrated that the addition of trace elements to stoichiometric HA tends to enhance its bioresorbability, its mechanical performances and/or its biological properties [[12], [13], [14]]. Regarding the improvement of angiogenesis, Mg-doped HAs have been the most studied compounds in the literature. Pure apatitic phases were obtained only for low magnesium concentrations (up to $0.6 \mathrm{wt} \%$ [15]). For higher content, Mg-doped HAs are unstable above $800^{\circ} \mathrm{C}$ and their decomposition occurs at lower temperatures with the increase of magnesium amount $[16,17]$. Cobalt-substituted HA has only been studied at low temperature (below $\left.600^{\circ} \mathrm{C}\right)[18,19]$ while Zykin et al. succeeded to embed dioxocobaltate anions in the HA lattice by solid-state reaction [20]. Using the same synthesis process, several authors obtained pure and thermally stable copperdoped HA (CuHA) crystals [[21], [22], [23], [24]]. In addition to the expected potential to stimulate angiogenic properties, copper is well known for its antibacterial effect $[25,26]$, so the development of copper-doped HA ceramics for bone reconstruction appears of a twofold interest.

Synthesis of CuHA powders can be performed by aqueous coprecipitation route. It leads to the substitution of calcium by copper and to a theoretical product $\mathrm{Ca}_{10-x} \mathrm{Cu}_{x}\left(\mathrm{PO}_{4}\right)_{6}(\mathrm{OH})_{2}$. In the literature, pure light blue compounds were obtained at low temperature (below $600^{\circ} \mathrm{C}$ ). XRD analyses showing lower cell parameters for CuHA than HA, the substitution of calcium by copper was confirmed [[27], [28], [29], [30], [31]]. However, none of the asprepared copper-doped hydroxyapatites was thermally stable above $800^{\circ} \mathrm{C}[[29],[30]$, [31]]. By solid state reaction, thermally stable CuHAs were synthetized but secondary phases of copper oxides and tricalcium phosphates (TCP) can also be observed [[32], [33], [34]]. The increase of the unit cell parameters with copper content and the detection of copper at the $2 b$ Wyckoff position $(0,0,0)$ by Rietveld analysis showed the copper insertion into the hexagonal channels leading to a theoretical $\mathrm{Ca}_{10}\left(\mathrm{PO}_{4}\right)_{6} \mathrm{Cu}_{x} \mathrm{O}_{y} \mathrm{H}_{z}$ composition [[21], [22], $[23], 33,34]$. Copper oxidation state is still not clearly established: mixed valences $\mathrm{Cu}^{+} / \mathrm{Cu}^{2+}[21,23,24,33]$, as well as $\mathrm{Cu}^{+} / \mathrm{Cu}^{3+}$ pairs are stated [22,34]. Literature mainly highlighted the crystallographic structure of CuHA powders but there is no available data regarding the sintering and microstructure of pure copper-substituted HA ceramics. Additionally, copper is known for its potential toxicity towards cells [35,36]. However, only few studies performed biocompatibility tests on copper-doped HA. Depending on the synthesis method and the in vitro culture protocol, the results diverge. For the same $\mathrm{Cu} / \mathrm{Ca}=0.01 \mathrm{M}$ ratio, CuHA pellets obtained from an ion exchange method, by Li et al., were cytotoxic after one day of incubation [37] whereas the biphasic pellets (1.4 wt\% of TCP) calcined at $1200^{\circ} \mathrm{C}$ by Gomes et al. were found to be biocompatible after one week of culture [33]. A cytotoxic concentration of copper ion released in the culture medium was found to be as low as $0.082 \mathrm{ppm}$ in the first study [37], while about $10 \mathrm{ppm}$ in the second one was not found toxic [33]. This last study also shows the major influence of the HA/TCP ratio on copper ion release and cell viability. Therefore, the chemical structure, the secondary phases as well as the microstructure of the tested compound may greatly influence the biocompatibility (e.g. by governing copper ion release from the material to the surrounding biological fluid). Consequently, it appears of prime importance to investigate both the sintering and the microstructure of pure apatitic phase CuHA ceramics.

This paper focuses on the processing of copper-doped hydroxyapatite ceramics by solid-state reaction sintering and on their microstructural characterization. Preliminary in vitro biological tests using MC3T3-E1 cell line was also performed to evaluate their biocompatibility. To this end, CuHAs ceramics with different copper concentrations from 0.8 to $10.7 \mathrm{wt} \%\left(\mathrm{x}=0.1-1.5 \mathrm{~mol}\right.$ in regard of the general formula $\mathrm{Ca}_{10}\left(\mathrm{PO}_{4}\right)_{6} \mathrm{Cu}_{\mathrm{x}} \mathrm{O}_{\mathrm{y}} \mathrm{H}_{z}$ were prepared.

\section{Material and methods}

\subsection{Samples preparation}




\subsubsection{Starting powders}

Pure calcium phosphate HA was first synthesized by a conventional aqueous precipitation method detailed in a previous work [38]. Briefly, a solution of diammonium hydrogenphosphate $\left(\mathrm{NH}_{4}\right)_{2} \mathrm{HPO}_{4}(1.55 \mathrm{M}, 1.2 \mathrm{~L}$; Fisher Scientific) was dropwise added to a calcium nitrate solution $\mathrm{Ca}\left(\mathrm{NO}_{3}\right)_{2} \cdot 4 \mathrm{H}_{2} \mathrm{O}(1.31 \mathrm{M}, 2 \mathrm{~L}$; Sigma-Aldrich). The $\mathrm{pH}$ of the liquid medium was maintained at 8.5 by addition of ammonium hydroxide $\mathrm{NH}_{4} \mathrm{OH}$ (Fisher Scientific) and the temperature was fixed at $85^{\circ} \mathrm{C}$. The solution was continuously stirred and refluxed under argon atmosphere in order to prevent the carbonation of HA. After total addition of the phosphate solution, the suspension was ripened for $5 \mathrm{~h}$. The precipitate was extracted by centrifugation, washed two times with distilled water, dried over night at $100{ }^{\circ} \mathrm{C}$ and grinded in a mortar. The as-prepared powder (around $200 \mathrm{~g}$ per synthesis) was annealed at $600^{\circ} \mathrm{C}$ for $1 \mathrm{~h}$ to eliminate the by-products. It will be referred as HA600. After precipitation and annealing at $600^{\circ} \mathrm{C}$, a pure $\mathrm{HA}$ phase was obtained. All the diffraction peaks indexed according to ICDD-PDF card $\mathrm{n}^{\circ} 9-0432$, corresponded to the HA crystal lattice (Fig. A1(a) - see appendix). Phase purity of the powder was checked and a Ca/P molar ratio of 1.667 was determined after calcination at $1000{ }^{\circ} \mathrm{C}$ for $15 \mathrm{~h}$ according to the standard specifications of ISO 13779-3:2018 [39].

A commercially available copper oxide powder was purchased (Alfa Aesar). The X-ray diffraction pattern of the raw $\mathrm{CuO}$ powder is given in Figure $\mathrm{A} 1(\mathrm{~b})$.

\subsubsection{Cu-doped HA powder blend and pellet preparation}

HA600 and copper oxide CuO powders were intimately mixed and milled by attrition (NETZSCH device). The following copper oxide weight contents were added to HA600: 0.8, 2.3, 3.8, 5.3 and 10.7 wt\% leading respectively to a copper content $x$ of $0.1,0.3,0.5,0.7$ and $1.5 \mathrm{~mol}$ in accordance with a general formula $\mathrm{Ca}_{10}\left(\mathrm{PO}_{4}\right)_{6} \mathrm{Cu}_{\mathrm{x}} \mathrm{O}_{\mathrm{y}} \mathrm{H}_{\mathrm{z}}$. Milling was carried out in water, with $1 \mathrm{wt} \%$ of dispersant Darvan $\mathrm{CN}$ (Vanderbilt Minerals) towards the total amount of powders. Attrition milling was carried out at $800 \mathrm{rpm}$, during $3 \mathrm{~h}$ in a Teflon container using yttrium-stabilized zirconia balls of $1 \mathrm{~mm}$ diameter. The volumetric particle size distributions of the initial raw powders $\mathrm{HA} 600$ and $\mathrm{CuO}$ oxides and of the $3 \mathrm{~h}$-milled suspension ns-CuHAO.5 are reported in Figure A2. The particle size distributions were determined using a laser particle size analyzer (Partica LA-950V2, Horiba). While the raw powders get particle size distribution with average size larger than $5 \mu \mathrm{m}$, the average particle size of the $\mathrm{CuO}-\mathrm{HA}$ mixture after attrition was around $1.5 \mu \mathrm{m}$. Attrition milling was performed because the particle size reduction improves the solid-state reaction between the two powders to form coppersubstituted CuHAx. The milled blends of $\mathrm{HA}$ and $\mathrm{CuO}$ powders will be referred as ns-CuHAx. Finally, they were dried over night at $100{ }^{\circ} \mathrm{C}$ and sieved at $80 \mu \mathrm{m}$.

Green pellets of ns-CuHAx blends were shaped by uniaxial pressing at $100 \mathrm{MPa}$ and sintered under air atmosphere from $900{ }^{\circ} \mathrm{C}$ to $1200^{\circ} \mathrm{C}$ with a dwell time of $30 \mathrm{~min}$ and a heating rate of $10^{\circ} \mathrm{C} / \mathrm{min}$. The CuHA bulk density was measured by helium pycnometry (AccuPyc II 1340, Micromeritics) after a grinding of the sintered pellets. Ten measurements were done. The apparent relative density of the pellets was measured by Archimede method from pellet immersion into water. The ratio of the apparent relative density on the bulk density gives access to the densification rate.

\subsection{Characterization techniques}

\subsubsection{Chemical analyses}

Copper content in Cu-doped HA was measured by ICP-OES (PerkinElmer Optima 8300). The apparatus was calibrated using standard solutions of copper and an average of 3 measures by sample was done. Samples were prepared by dissolving $15 \mathrm{mg}$ of powder in $6 \mathrm{~mL} \mathrm{HNO} 3-\mathrm{HCl}(3: 2)$ heated by microwave radiations. Then, the solution was diluted in distilled water to reach a total volume of $100 \mathrm{~mL}$. To focus on the chemical composition, 
infrared spectra of the samples were obtained on a Spectrum One FTIR spectrometer from PerkinElmer. 32 scans were recorded between 4000 and $400 \mathrm{~cm}^{-1}$ with a $4 \mathrm{~cm}^{-1}$ resolution using the $\mathrm{KBr}$ pellet method.

\subsubsection{X-ray diffraction}

(i) - Temperature reaction between $\mathrm{HA}$ and copper oxide was investigated by means of temperature programmed XRD using a furnace (HTK1200 N, Anton PAAR) mounted into a Brüker D8 Advance Da Vinci diffractometer with a Bragg-Brentano geometry. A pellet of the ns-CuHA0.5 powder was shaped. XRD patterns were collected from 23 to $43^{\circ}(2 \theta)$ with a step size of $0.02^{\circ}$ and a step time of $1.5 \mathrm{~s}$. A Cu Ka radiation was used at $40 \mathrm{kV}$ and $40 \mathrm{~mA}$. In situ XRD acquisitions were performed every $50^{\circ} \mathrm{C}$ from 900 to $1150{ }^{\circ} \mathrm{C}$ as follows: ramp of $10^{\circ} \mathrm{C} / \mathrm{min}$, dwell time of $15 \mathrm{~min}$ at the desired temperature to stabilize the system before the pattern acquisition of 30 min duration.

(ii) - Phase purity of CuHAx samples was confirmed by XRD patterns collected at room temperature with a Brüker D8 Advance Serie II diffractometer equipped with a $\mathrm{Cu} K \alpha 1$ radiation X-ray tube and a rear monochromator. Acquisitions were operated at $40 \mathrm{kV}$ and $40 \mathrm{~mA}$ from 10 to $60^{\circ}(2 \theta)$ using a step size of $0.02^{\circ}$ and a step time of 1.4s. Samples were rotated at $10 \mathrm{rpm}$ during the measurements to avoid particle orientation effects. The crystal structure of the apatite phases was refined in space group $P 6_{3} / m$ using the FullProf program.

\subsubsection{Thermal analyses}

(i) - The thermal behaviour of pure HA and CuHAx was investigated by thermogravimetry coupled with differential thermal analysis (TG/DTA, STA 449 F3 Jupiter, NETZSCH). The HA600 powder and a mixture containing $80 \mathrm{wt} \%$ of $\mathrm{HA600}$ and $20 \mathrm{wt} \%(\mathrm{x}=3.2)$ of copper oxide were analysed (CuHA3.2). This high amount of $\mathrm{CuO}$ was chosen voluntary to allow the easiest identification of the thermal effects occurring between $\mathrm{HA}$ and $\mathrm{CuO}$ by making them as intense as possible. Indeed, it corresponds to an excess of $\mathrm{CuO}$ which cannot react completely with HA. Measurements were performed up to $1500^{\circ} \mathrm{C}$ with a heating rate of $20^{\circ} \mathrm{C} / \mathrm{min}$ under air flow.

(ii) - The sintering behaviour of the ceramics was followed by dilatometry using a thermomechanical analyzer SETSYS evolution (SETARAM instrumentation). A contact force of $5 \mathrm{~g}$ was applied on the green ns-CuHAx pellets. Pellets were heated up to $1250^{\circ} \mathrm{C}$ during $30 \mathrm{~min}$ with a heating rate of $10{ }^{\circ} \mathrm{C} / \mathrm{min}$ under air flow.

\subsubsection{Electron microscopy (SEM)}

(i) - The surface of the sintered pellets was imaged by SEM with a Zeiss microscope LEO 1530 VP. The working distance was fixed at $5 \mathrm{~mm}$, the EHT at $1 \mathrm{kV}$ and a secondary electron detector was used. The average grain size of the pellets was determined via the ImageJ software. Different areas were analysed collecting grain size distribution on a set of 300 grains or more.

(ii) - Elemental cartography was imaged on a field emission electron microscope JEM 2100F (JEOL, $200 \mathrm{kV}$ field emission) coupled with an energy dispersive $\mathrm{X}$-ray spectrometer. A lamella of a few hundred nanometers was cut in the bulk of a sintered pellet using a FIB-SEM (Zeiss Crossbeam 550). A copper holder was used to fix the sample, which did not allow making a quantitative analysis of copper.

\subsection{In vitro biological assays}

\subsubsection{Ceramic substrates preparation}

Before the biological assays, pellets of pure $\mathrm{HA}$ and CuHAx were sintered respectively at $1200^{\circ} \mathrm{C}$ and $1100{ }^{\circ} \mathrm{C}$ for $1 \mathrm{~h}$. The substrates were polished using a series of silicon carbide grits (P600 to P4000) and sterilised at $200{ }^{\circ} \mathrm{C}$ for $2 \mathrm{~h}$ at least under air atmosphere. Finally, they were equilibrated during $1 \mathrm{~h}$ into a culture plate (Thermo Fisher Scientific) in complete alpha modified Eagle's medium MEM- $\alpha$ (Gibco) without ascorbic acid and supplemented with $10 \%$ fetal calf serum (Invitrogen), $50 \mathrm{UI} \cdot \mathrm{mL}^{-1}$ penicillin and $50 \mu \mathrm{g} \mathrm{mL}^{-1}$ streptomycin 
(Gibco) in an incubator heated at $37{ }^{\circ} \mathrm{C}$ under $5 \% \mathrm{CO}_{2}$ wet atmosphere. This culture medium is hereafter called growth medium - GM.

\subsubsection{Cell culture and seeding}

Pre-osteoblastic cells MC3T3-E1 subclone 14 (ATCC, then referred as MC3T3-E1) were routinely cultured in GM in an incubator heated at $37{ }^{\circ} \mathrm{C}$ under $5 \% \mathrm{CO}_{2}$ wet atmosphere. The medium was replaced every 2-3 days and cells were split when the cell confluence reached $70-80 \%$ of the culture area. After counting cells on a Malassez haemocytometer, an amount of 10,000 cells $/ \mathrm{cm}^{2}$ was seeded dropwise onto the HA and CuHAx pellets in GM. Cells were cultured at $37{ }^{\circ} \mathrm{C}$ under $5 \% \mathrm{CO}_{2}$ wet atmosphere for 1,3 and 5 days for the viability assays and 7 days for the differentiation tests. These time points were chosen because the MC3T3 Subclone 14 cells exhibit a high level of differentiation after growth in ascorbic acid and 3-4 $\mathrm{mM}$ inorganic phosphate. They form a well mineralized extracellular matrix (ECM) after 10 days (ATCC technical datasheet). Thus, this cell line allowed us to check abnormalities of the differentiation process in the early times of cell culture. The classical time points for the study of differentiation are 3, 7, 14 and 21 days, the two later are usually for characterizing the mineralization step which is conditioned by the completion of the initial phases of cell differentiation.

\subsubsection{Cell viability}

The viability of MC3T3-E1 cells was tested by using the AlamarBlue ${ }^{\circledR}$ reagent (Thermo Fisher Scientific, USA). An amount equal to $10 \%$ of the well volume was added at the beginning of the cell culture. The AlamarBlue ${ }^{\circledR}$ reduction, resulting in a colour change from blue to pink over incubation time, reflects the metabolic activity of the growing cells. The fluorescence of AlamarBlue ${ }^{\circledR}$ was measured before the end of the incubation time at $585 \mathrm{~nm}$ with a FLUOstar OPTIMA spectrophotometer (BMG Labtech, Germany). The results were normalized on the HA sample after $2 \mathrm{~h}$ incubation. Viable cells were stained immediately after with $10 \mu \mathrm{M}$ calcein red-orange AM (ThermoFisher), incubated during $15 \mathrm{~min}$ at $37^{\circ} \mathrm{C}$ and rinsed in $\mathrm{GM}$. All the nuclei were then stained by incubating the cells with $20 \mu \mathrm{M}$ Hoescht 33342 for $5 \mathrm{~min}$. Pellets were observed by fluorescence microscopy (Axiolmager, Carl Zeiss). The ratio of calcein positive cells to the total cells (number of nuclei) was used to calculate the viability rate. For each experiment, the analysis was performed on a minimum of five fields and more than 1000 cells were counted.

\subsubsection{Cell differentiation}

MC3T3-E1 cells were seeded at a density of 15,000 cells $/ \mathrm{cm}^{2}$ in 12 -well plates containing ceramic pellets in a differentiation medium (DM) consisting in GM with the addition of $100 \mathrm{nM}$ dexamethasone (AppliChem), $10 \mathrm{mM}$ beta-glycerophosphate (AppliChem) and $50 \mu \mathrm{M}$ I-ascorbic acid (Sigma Aldrich). Two controls were done without ceramic material: cells in GM and in DM were respectively used as negative and positive controls. After 3 days of culture, the medium was changed to fresh medium. Cells were lysed and RNA extracted using a commercial kit according the instruction of the manufacturer (RNeasy ${ }^{\circledR}$ Plus Micro kit, Qiagen) with a modification as previously described [12]. Eluates from RNA isolation on the column were kept at $-20{ }^{\circ} \mathrm{C}$ for protein precipitation and extraction according to the protocol set up by Morse et al. [40]. The concentration of the precipitated proteins was measured for each sample by spectrophotometry at $280 \mathrm{~nm}$ (Nanodrop, ThermoFisher). For each condition, $15 \mu \mathrm{g}$ of heat-denaturated proteins were loaded on $10 \%$ polyacrylamide gels and separated by electrophoresis. Then, the proteins were transferred on $0.45 \mu \mathrm{m}$ polyvylidene fluoride membranes (Biorad). After the saturation of the specific antigenic sites, the membranes were first hybridized with primary antibodies overnight at $4{ }^{\circ} \mathrm{C}$ and then with the appropriate secondary antibody (goat anti-rabbit; goat anti-mouse or mouse anti-goat) coupled to the Horse Raddish Peroxydase (all from Dako) for $1 \mathrm{~h}$ at RT. The proteins of interest were detected by chemiluminescence using a luminol-based reagent (Millipore) using a G-Box system (Syngene). The primary antibodies used in this study were: mouse anti RUNX2 (Abcam), goat anti-osteopontin (R\&D), and mouse anti GAPDH (Santa-Cruz Biotechnology). Analysis of the western blots was done using the ImageJ software and the densities of the signals of interest were normalized to those of GAPDH. 


\subsubsection{Statistics}

The calcein viability tests and the differentiation tests were conducted with three independent in vitro experiments for each ceramic group. For the AlamarBlue ${ }^{\circledR}$ reduction, one and two independent experiments were considered respectively for 1 and 3 days while three independent experiments have been performed for 4 and 5 days. Data were assayed for normality using the Shapiro-Wilk test using PAST [41]. According to the data set and normality test results, the Kruskal-Wallis test was followed by a Dunn's post hoc test, or one-way analysis of variance (ANOVA) was performed followed by a Tukey's multiple comparison test using GraphPad Prism 6. Differences were considered significant for $p<0.05$.

\section{Results and discussion}

\subsection{Solid-state reaction between $\mathrm{HA}$ and $\mathrm{CuO}$}

In a first step, temperature programmed XRD was performed on ns-CuHA0.5 powder. The HA and CuO phases of the powder blend are detected up to $950{ }^{\circ} \mathrm{C}$ (Fig. 1a). The reaction occurs at a temperature around $1000{ }^{\circ} \mathrm{C}$. A pure apatite phase is detected above this temperature; no secondary crystalline phase is identified in the compound. This indicates that copper is fully incorporated in the apatite lattice to produce a copper substituted HA (CuHAx).
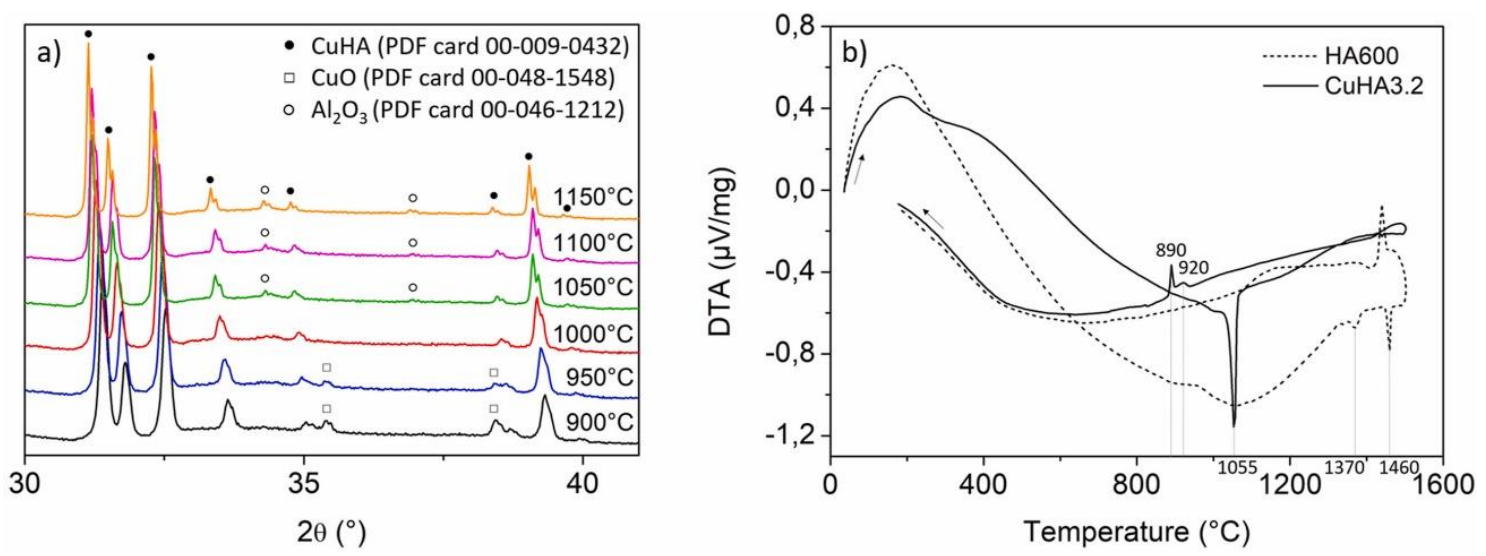

Fig. 1. Temperature programmed XRD of ns-CUHAO.5 samples, peaks associated with corundum are due to the alumina sample holder (a) and DTA measurement on CUHA3.2 sample, powder blend containing $80 \mathrm{wt} \%$ of HA600 and $20 \mathrm{wt} \%$ $x=3.2 \mathrm{~mol}$-of CuO (b).

On the DTA curve of pure HA (Fig. 1b), the wide endothermic effect from $950{ }^{\circ} \mathrm{C}$ and the small endothermic peak at $1370{ }^{\circ} \mathrm{C}$ are due to its dehydroxylation (Eq. (1)). Then, the formed oxyapatite decomposes into $\alpha$ tricalcium phosphate and tetracalcium phosphate monoxide at $1460{ }^{\circ} \mathrm{C} \mathrm{(Eq.} \mathrm{(2)).} \mathrm{These} \mathrm{endothermal} \mathrm{reactions}$ are reversible in air atmosphere: exothermic effects at similar temperatures can be seen during cooling to room temperature. These two well-documented reactions are typical of HA samples [38,42].

$\mathrm{Ca}_{10}\left(\mathrm{PO}_{4}\right)_{6}(\mathrm{OH})_{2} \rightarrow \mathrm{Ca}_{10}\left(\mathrm{PO}_{4}\right)_{6}(\mathrm{OH})_{2-2 x} \mathrm{O}_{x}+\mathrm{xH}_{2} \mathrm{O}(\mathrm{x} \leq 1)$

$\mathrm{Ca}_{10}\left(\mathrm{PO}_{4}\right)_{6} \mathrm{O} \rightarrow 2 \mathrm{Ca}_{3}\left(\mathrm{PO}_{4}\right)_{2}+\mathrm{Ca}_{4} \mathrm{O}\left(\mathrm{PO}_{4}\right)_{2}$

In presence of copper, a sharp and intense endothermic phenomenon is observed during heating with a maximum at $1055^{\circ} \mathrm{C}$. The temperature at which this effect begins is difficult to assess because of the presence of a secondary endothermic shoulder. This main peak is associated with the reaction between $\mathrm{HA}$ and $\mathrm{CuO}$ to form copper substituted HA. Indeed, the temperature is in agreement with the reaction temperature detected from in situ XRD analyses. Surprisingly, the formed CuHA phase does not dehydrate or decompose up to $1500{ }^{\circ} \mathrm{C}$, so the presence of copper ions seems to stabilize the apatite structure at higher temperature. 
According to the Ellingham diagram relative to copper element, the reduction of $\mathrm{CuO}$ into $\mathrm{Cu}_{2} \mathrm{O}$ occurs at $960{ }^{\circ} \mathrm{C}$ in atmospheric air conditions $\left(\mathrm{PO}_{2}=0.2 \mathrm{bar}\right.$, see fig. A.5). The endothermic shoulder registered during heating around this temperature in the foot of main endothermic peak of copper-HA reaction can be associated to the reduction of copper oxide that has not yet reacted with HA. During cooling, two exothermic peaks are observed with maxima at $920^{\circ} \mathrm{C}$ and $890^{\circ} \mathrm{C}$. Therefore, these two peaks may be due to the reoxidation of the remaining $\mathrm{Cu}_{2} \mathrm{O}$ phase that has not reacted with $\mathrm{HA}$. Indeed, in this experiment a very high amount of copper oxide was used (i.e. 20 wt $\%-x=3.15$ ), which is over the maximum amount leading to pure CuHA compounds after reaction, as exposed in the following paragraph (see Fig. $3 \mathrm{~b}$ for $\mathrm{x}=1.5$ ). These results show that a copper-doped hydroxyapatite phase stable up to $1500^{\circ} \mathrm{C}$ can be obtained by solid-state reaction from $950{ }^{\circ} \mathrm{C}$. Furthermore, the introduction of copper ions into the apatite structure occurs while there is a partial reduction of the copper oxidation state.
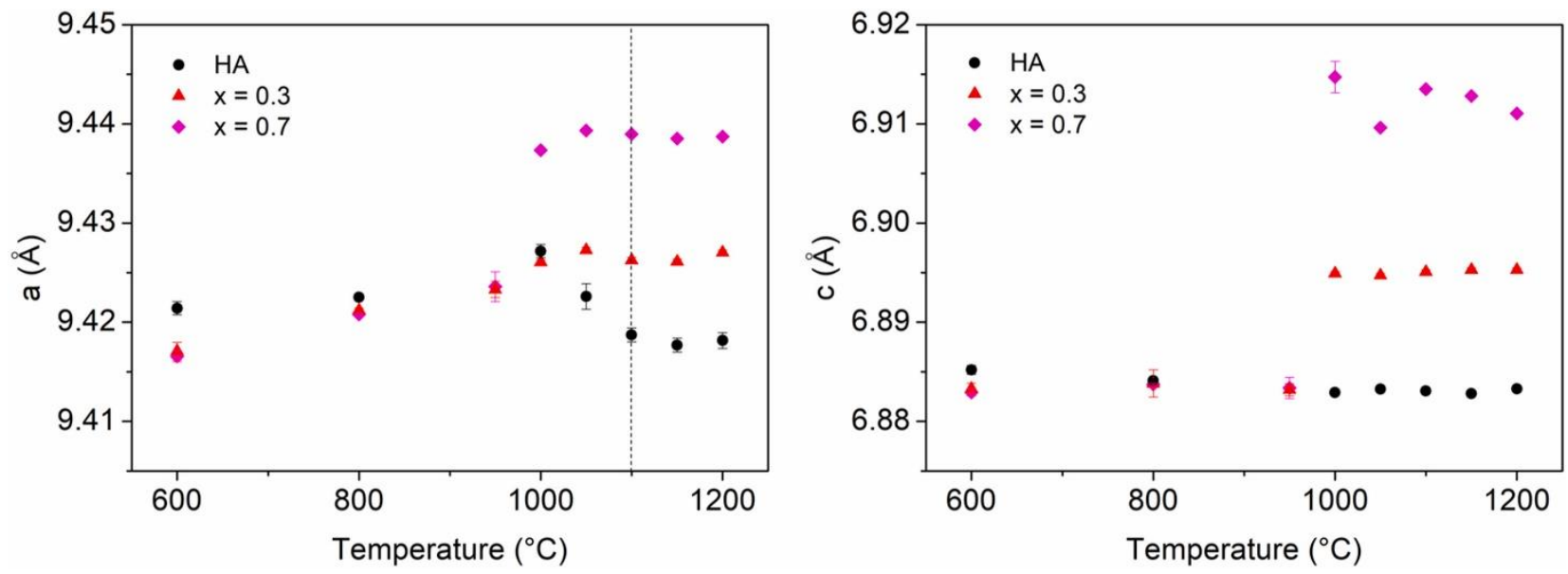

Fig. 2. Evolution of the lattice parameters $a$ and cof the apatite phase in pure HA, CUHAO.3 and CuHAO.7 powders vs the calcination temperature (dwell time $1 \mathrm{~h}$ ).

a)

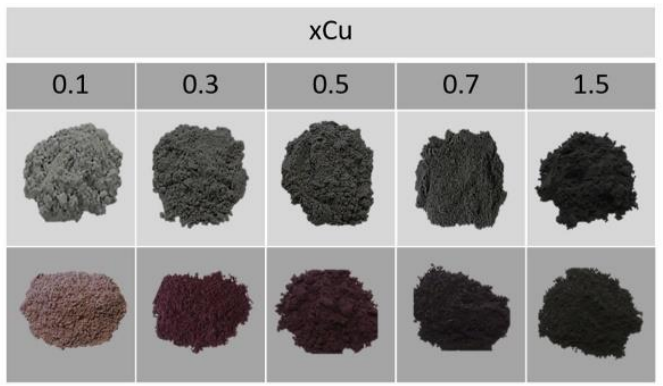

c)

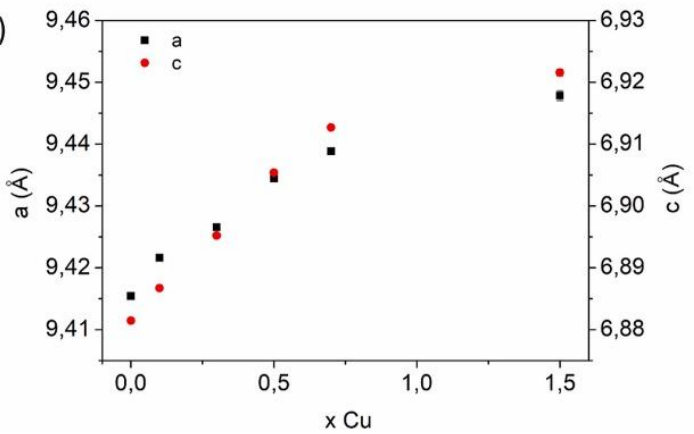

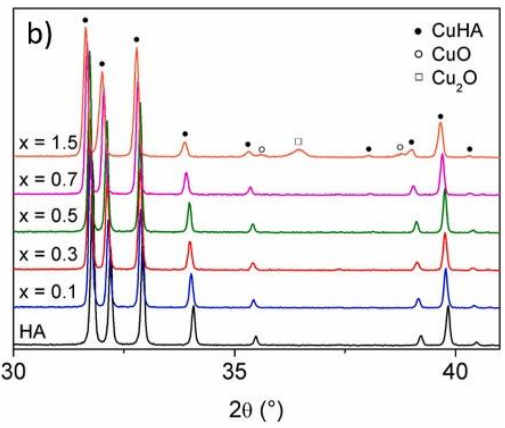

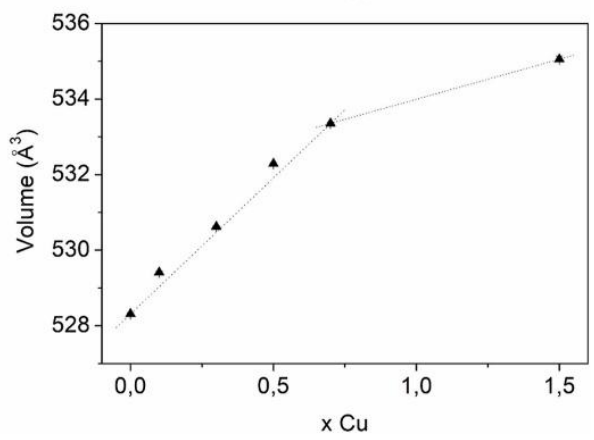

Fig. 3. CuHAx powders characterisation. Initial blends of HA and CuO powders ns-CUHAx (top) and CuHAx powders (bottom) obtained after grinding pellets sintered at $1100{ }^{\circ} \mathrm{C}$ for $1 \mathrm{~h}(\mathrm{a})$ with the XRD patterns (b) and the lattice parameters and volume of the sintered powdery samples, the error bars do not exceed the symbol size (c). 
Pellets of pure HA600, ns-CuHA0.3 and ns-CuHA0.7 mixtures were heated at different temperatures from $600{ }^{\circ} \mathrm{C}$ to $1200^{\circ} \mathrm{C}$ for $1 \mathrm{~h}$ and the lattice parameters of the formed apatite were refined from XRD patterns to evaluate the influence of the temperature and copper amount on the kinetics of copper incorporation (Fig. 2). The lattice parameters $a$ and $c$ of the apatite phase remains the same below $800^{\circ} \mathrm{C}$, an abrupt deviation occurs between 800 and $1050^{\circ} \mathrm{C}$ leading to an increase of the unit-cell parameters with the copper concentration. Then, from $1050^{\circ} \mathrm{C}$ both $a$ and $c$ lattice parameters are constant whatever the copper content. The decrease of the $a$ parameter for pure $\mathrm{HA}$ from $1000^{\circ} \mathrm{C}$ is due to its dehydroxylation that occurs from this temperature. This phenomenon is quite not observed on CuHAx compounds. Thus, the incorporation of copper appears completed from $1050^{\circ} \mathrm{C}$. The influence of the dwell was studied at $1100^{\circ} \mathrm{C}$. The lattice parameters remain constant for dwell durations between 0.5 and $4 \mathrm{~h}$ (data not shown).

Finally, ns-CuHAx blends of raw $\mathrm{HA}$ and $\mathrm{CuO}$ powders were die pressed into pellets and sintered at $1100{ }^{\circ} \mathrm{C}$ for $1 \mathrm{~h}$ to investigate the influence of the copper amount, as these sintering conditions allow to complete the reaction of copper oxide with HA. After thermal treatment, pellets were crushed into powder before analysis. A colour change of the pellets, from grey to purple is observed (Fig. 3a). On the XRD patterns (Fig. 3b), a pure apatite phase is obtained up to $x=0.7$. For the pure phases, experimental copper contents measured by ICPOES are similar to those introduced in the powder blend. The presence, besides the main apatite phase, of both cupric $\mathrm{CuO}$ and cuprous $\mathrm{Cu}_{2} \mathrm{O}$ oxides for $\mathrm{x}=1.5$ confirms the partial reduction of $\mathrm{Cu}^{\prime \prime}$ in $\mathrm{Cu}^{\prime}$ stated from DTA. The mixed valence of copper in the copper-substituted apatite explains the purple colour of the ceramic pellets,

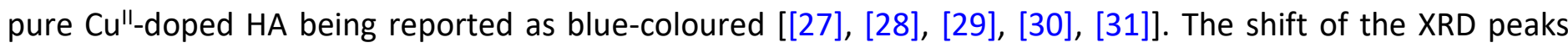
towards small angles is associated to a linear increase of the lattice volume and parameters of the apatite phase with copper amount (Fig. $3 \mathrm{c}$ ). The plot of the unit-cell volume versus copper content shows a slope decrease between $x=0.7$ and $x=1.5$ compositions which is in agreement with a limit of copper insertion in the HA lattice and the presence of secondary phases of copper oxides in the CuHA1.5 compound.

FTIR spectra show that all the heated samples exhibit the bands characteristic of apatite structure (Figure A3) $[38,43]$. Two regions are of particular interest: the first one from 400 to $1200 \mathrm{~cm}^{-1}$, mainly characteristic of the phosphate groups (Fig. 4a) and the second one from 3000 to $4000 \mathrm{~cm}^{-1}$ corresponds to the hydroxyl group vibrations (Fig. 4b). In the range $950-1100 \mathrm{~cm}^{-1}$, the bands are assigned to the $\mathrm{P}-\mathrm{O}$ stretching vibration of the phosphate groups while the bands from 430 to $605 \mathrm{~cm}^{-1}$ correspond to the phosphate bending vibration. The stretching vibration of the single hydroxyl groups gives bands around 3570 and $630 \mathrm{~cm}^{-1}$. With the increase of copper content, the two latter bands decrease in intensity, which suggests that copper substitutes the hydrogens of the hydroxyl groups into the hexagonal channels. Three new bands also appear at 3425, 3340 and $3230 \mathrm{~cm}^{-1}$, which must correspond with hydroxyl group vibrations in modified environments due to the close neighbouring of copper. This was already observed in the literature [21,23]. The OH groups can be affected either by their direct bonding with copper atom or indirectly by hydrogen bonding $\mathrm{Cu}-\mathrm{O}-\mathrm{H}-\mathrm{O}$ in copper neighbouring [21,[44], [45], [46], [47]]. Insertion of copper in the hexagonal channels of hydroxyl location is also supported by the increase of the lattice parameters. Indeed, the smaller ionic radius of copper would have led to a decrease of the lattice parameters in case of a copper for calcium substitution in the apatite. Unit-cell volume expansion relates to the insertion of copper in the apatite structure along the $\mathrm{OH}$ channels. Similar results were previously reported in the literature [22,33,34]. New IR bands also appear in the range 675$900 \mathrm{~cm}^{-1}$ : two weak bands are observed at 675 and $760 \mathrm{~cm}^{-1}$ and three others around 810,840 and $865 \mathrm{~cm}^{-1}$. This region can be associated with $\mathrm{Cu}-\mathrm{O}$ vibrations. The $\mathrm{Cu}-\mathrm{O}-\mathrm{H}$ bonds give bending absorptions at different frequencies depending on the strength of the hydrogen bonding $[21,44,45]$. The results, especially the hydroxyl group IR band splitting, confirm the insertion of copper into the HA hexagonal channels. 

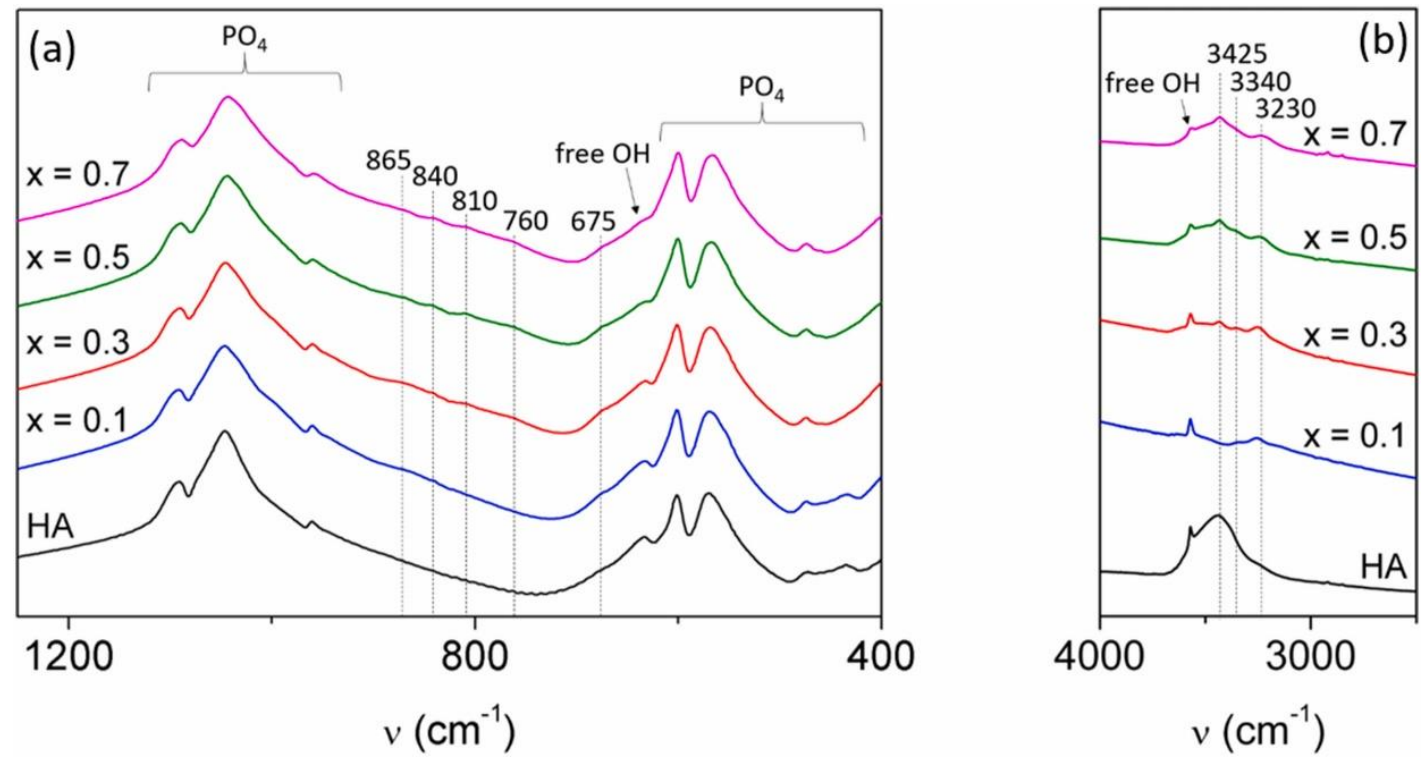

Fig. 4. FTIR spectra of HA600 and CUHAx powdery samples prepared by grinding pellets sintered at $1100{ }^{\circ} \mathrm{C}$ for $1 \mathrm{~h}$, zoom on the phosphate group region (a) and the hydroxyl group region (b).

Finally, the overall results show that pure copper-substituted HA containing up to 0.7 mol of copper can be obtained by solid state reaction from $1050{ }^{\circ} \mathrm{C}$. Copper of mixed valence I and II is inserted in the apatite lattice along with the $\mathrm{OH}$ channel. The disappearance of some hydrogens for charge balance conducts to propose the following formula for the apatite phase of CuHAx after thermal treatment: $\mathrm{Ca}_{10}\left(\mathrm{PO}_{4}\right)_{6} \mathrm{Cu}_{2}{ }_{2} \mathrm{Cu}_{x} \mathrm{O}_{2} \mathrm{H}_{2-2 x}$ with $x=y+z$. An advanced structural analysis to determine the exact positions and oxidation degrees of copper in the apatite lattice, including in particular ${ }^{1} \mathrm{H}$ and ${ }^{31} \mathrm{P}$ nuclear magnetic resonance (NMR), extended X-ray absorption fine structure (EXAFS), electron paramagnetic resonance (EPR), diffuse reflectance (DR) spectroscopies and XRD refinements was carried out [48]. The results will be published elsewhere.

\subsection{Sintering}

Only mixtures leading to apatite monophasic compounds were investigated in this part (i.e. CuHAx with $\mathrm{x}$ up to $0.7 \mathrm{~mol}$ ). The dilatometric shrinkage curves show that the temperatures of sintering onset (beginning of the pellet shrinkage) and maximum sintering rate (inflexion point of the shrinkage curve or minimum on derivative curve) are similar for the pure HA and the CuHAx pellets (Fig. 5a). The sintering begins around $700{ }^{\circ} \mathrm{C}$ and the maximum rate for $\mathrm{HA}$ is around $1010{ }^{\circ} \mathrm{C}$ with a light shift that does not exceed $20^{\circ} \mathrm{C}$ towards high temperatures for CuHAx. Therefore, copper does not influence the sinterability of HA. As the temperature reaction between $\mathrm{HA}$ and $\mathrm{CuO}$ is close to the sintering temperature, a direct "reaction-sintering" can be used to produce ceramic parts. To investigate this possibility, the influence of the sintering temperature, for a dwell time of $30 \mathrm{~min}$, on the final densification of CuHAx ceramics was studied. Dense monophasic ceramics made of pure apatite crystalline phase are obtained from ns-CuHAx biphasic mixtures with a densification rate higher than $96 \%$ from $1100{ }^{\circ} \mathrm{C}$ for $30 \mathrm{~min}$ (Fig. 5b), which confirms the possibility to achieve reaction sintering. The densification rates of pure HA and CuHA0.1 slightly increase from 1050 to $1200^{\circ} \mathrm{C}$ temperatures while there is no evolution or even a light decrease for higher copper contents. This phenomenon is visible at $1200{ }^{\circ} \mathrm{C}$ for which the ceramics with the lowest copper rate (CuHA0.1) have a densification rate close to $99 \%$ while it is only of $96 \%$ for the other CuHAx ceramics. It may be due to the classical Ostwald ripening due to grain coarsening in some ceramic materials at high temperature. 

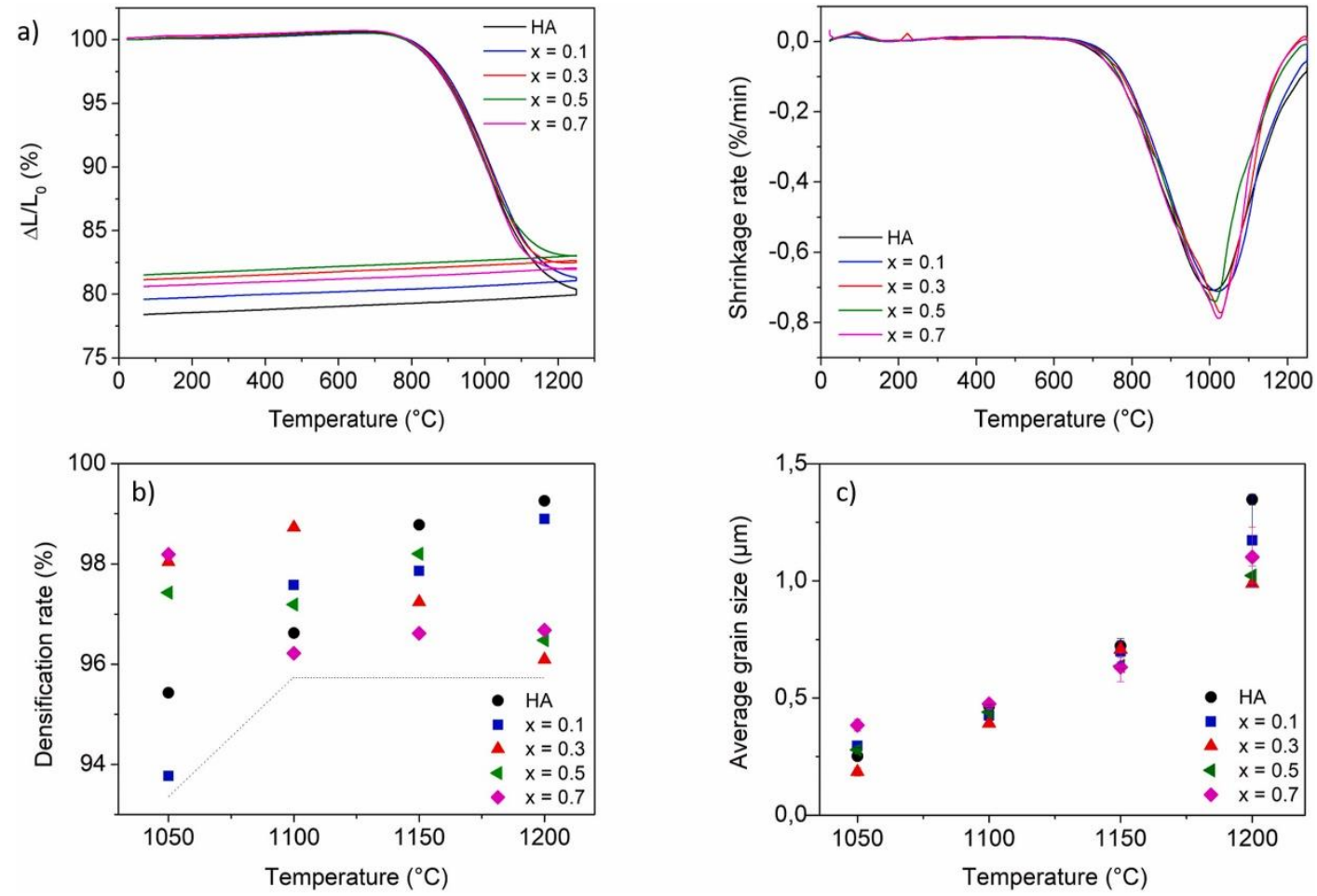

Fig. 5. Dilatometric shrinkage curves of HA600 and CuHAx pellets and derivative plot of densification vs the temperature (a), densification rate of ceramic parts after sintering for $1 \mathrm{~h}$ at different temperatures (b) and the associated grain size (c).

Regarding the microstructures of the ceramics, the average grain size, determined from SEM images of pellets surface (examples can be found in Figure A4), increases according to an exponential law with the temperature in the range $1050-1200^{\circ} \mathrm{C}$ (Fig. $5 \mathrm{C}$ ). Average grain size remains submicrometric up to $1150^{\circ} \mathrm{C}$, so temperatures between 1100 and $1150^{\circ} \mathrm{C}$ seems to be optimal to manufacture pure dense copper-substituted hydroxyapatite ceramics having fine microstructures. Two types of grains are observed on SEM images at the pellet surface (Fig. 6a). The amount of the "light" grains increases proportionally to the copper rate (Fig. 6c) but remains stable for each composition whatever the sintering temperature may be from $1050{ }^{\circ} \mathrm{C}$ to $1200{ }^{\circ} \mathrm{C}$ (see figure $\mathrm{A} 4$ in the case of CUHA0.5 for example). STEM-EDX cartographies of phosphorus, calcium and copper on a bulk lamella exhibit the presence of copper-rich compositions at the grain boundaries (Fig. 6b).

Two hypotheses can be put forward to explain these results. On the one hand, copper segregation at the grain boundaries has already been observed in copper-rich phase due to oxido-reduction mechanisms [49,50]. As mentioned above, during heating, $\mathrm{Cu}^{\prime \prime} \mathrm{O}$ reduces into $\mathrm{Cu}_{2}{ }_{2} \mathrm{O}$ above $960{ }^{\circ} \mathrm{C}$ and copper, mainly in $\mathrm{Cu}^{\prime}$ form, is incorporated into the apatite structure. However, $\mathrm{Cu}^{\prime}$ is only stable at high temperatures, so during cooling to room temperature, some $\mathrm{Cu}^{+}$ions (located near the material surface) could have been oxidized into $\mathrm{Cu}^{2+}$. This oxidation would be accompanied with the migration of part of this species to leave the apatite structure in order to maintain the crystal charge balance, forming thus copper-rich grain boundaries. On the other hand, Zykin et al. [34] showed that the solubility of copper (at the equilibrium) in the HA lattice grows with the temperature and indicates a reversible incorporation-deposition of copper in HA on the thermal treatment. 

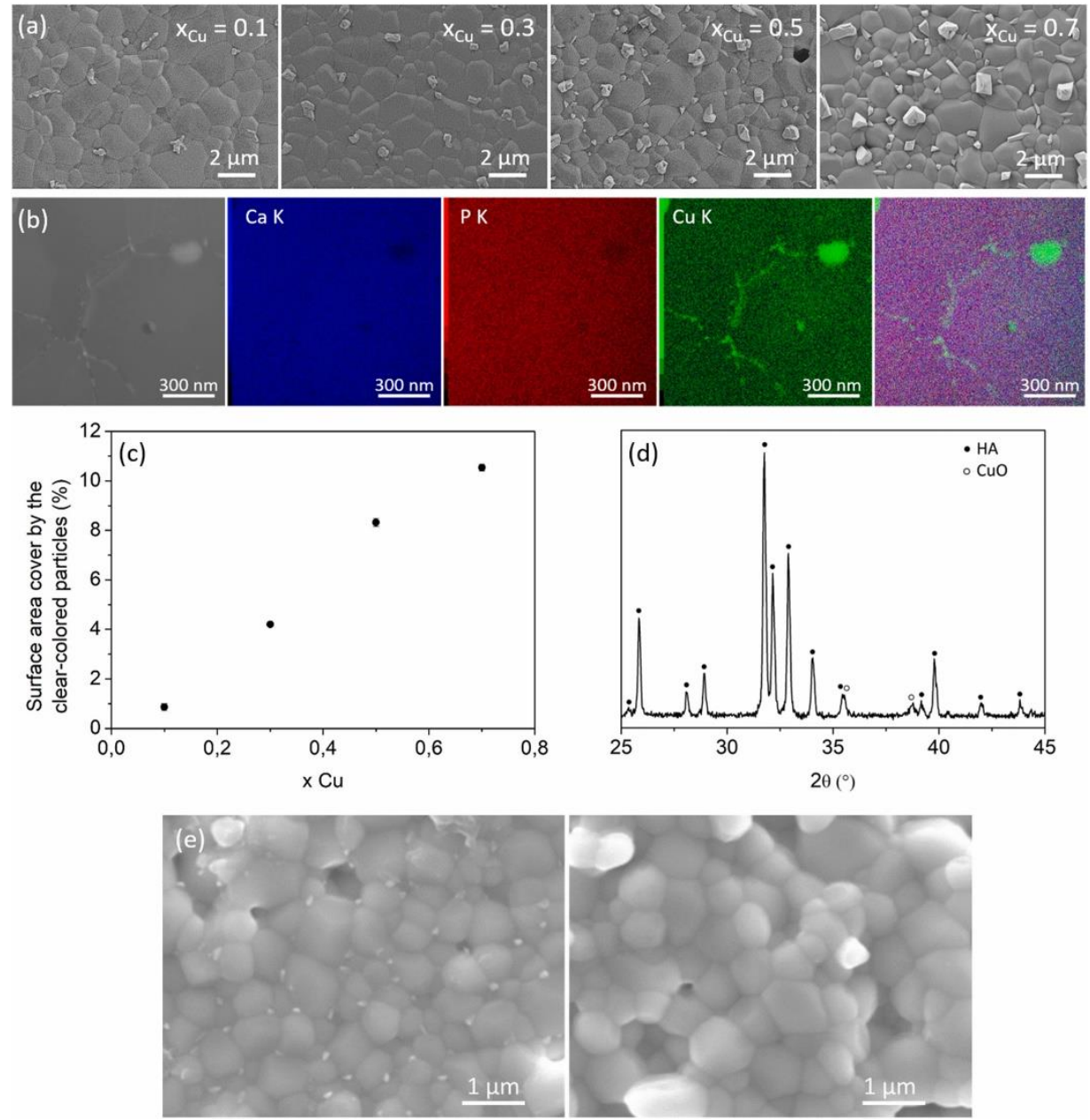

Fig. 6. SEM micrographs of CUHAx ceramics surface after sintering at $1200^{\circ} \mathrm{C}$ for $30 \mathrm{~min}$ (a); Calcium, phosphorus and copper STEM-EDX cartographies of CUHA0.7 sample sintered at $1200^{\circ} \mathrm{C}-30 \mathrm{~min}(\mathrm{~b})$; Percentage of surface area covered by the "light" particles, the error bars do not exceed the symbols (c); XRD pattern of CUHAO.5 ceramic surface after sintering at $1100^{\circ} \mathrm{C}-30 \mathrm{~min}$ and annealed at $500^{\circ} \mathrm{C}$ for $1 \mathrm{~h}(\mathrm{~d})$; SEM micrographs of CUHAO 0.7 sintered at $1200^{\circ} \mathrm{C}-30 \mathrm{~min}$ and quenched from the sintering to the room temperature in air (left) or in water (right) (e).

This hypothesis appears highly consistent with regard to our result. Indeed, some of the copper incorporated at high temperature in the HA crystals could have migrated to the grains surface (i.e. at the grain boundary) during cooling to room temperature due to the temperature dependent solubility. Annealing the samples at $500{ }^{\circ} \mathrm{C}$ for $1 \mathrm{~h}$ after sintering confirmed the reversibility of $\mathrm{Cu}$ incorporation in the HA. A change of colour of the pellets from purple to grey was observed ad the DRX patterns of the ceramics surface showed the presence of copper oxide (Fig. 6d). Conversely, the purple colour remained after quenching in air or in water from the sintering temperature to room temperature and the concentration of "light" grains decreased in air to disappear totally in water. Thus, demixion occurs while, during the cooling down, new $\mathrm{CuO}$ is formed from $\mathrm{Cu}^{+}$ previously incorporated in the HA. In agreement with Ellingham diagram of copper (figure A5), the demixion seems to proceed due to the oxidation of $\mathrm{Cu}^{+}$into $\mathrm{Cu}^{2+}$, showing thus the difficulty for the HA network to incorporate $\mathrm{Cu}^{2+}$ cations (hence, it tends to confirm the majority of + l oxidation state of copper in the HA lattice). The temperature of oxidation under air atmosphere is about $900{ }^{\circ} \mathrm{C}$, which also explains that a quenching from $1100{ }^{\circ} \mathrm{C}$ (from $\mathrm{Cu}^{+}$stability domain in Ellingham diagram) to room temperature allows to keep a large amount of copper $+\mathrm{I}$ inside the HA structure in comparison with a slow cooling down.

On the overall, these results agree with a thermodynamical metastability of the CuHAx phase at room temperature. They also show the importance of an accurate characterisation of the sintered ceramics, requiring complementary techniques to ensure that phase pure apatitic materials are produced. 
Finally, dense monophasic ceramics made of copper-substituted $\mathrm{HA} \mathrm{Ca}_{10}\left(\mathrm{PO}_{4}\right)_{6} \mathrm{Cu}_{z}^{\prime \prime} \mathrm{Cu}_{y} \mathrm{O}_{2} \mathrm{H}_{2-2 z-y}(\mathrm{y} \gg \mathrm{z})$ with a fine microstructure can be produced by reaction-sintering between mixtures of $\mathrm{HA}$ and $\mathrm{CuO}$ powders providing adjusted thermal treatments are performed.

\subsection{Preliminary in vitro biological behaviour}

For the cell culture experiments, pellets of pure $\mathrm{HA}$ and CuHAx $(\mathrm{x} \leq 0.7)$ were sintered respectively at $1200^{\circ} \mathrm{C}$ and $1100{ }^{\circ} \mathrm{C}$ for $1 \mathrm{~h}$ to ensure a high densification rate. Taking HA pellets as reference, no change in the cell viability is observed after 1 and 3 days of culture on CuHAx samples. The observation of the viable cell morphology after 3 days of culture (Fig. 7c, upper panel) does not highlight any effect of the presence of copper in the ceramic. The cells are well spread with a comparable morphology and they seem to be healthy. After 5 days, the cell viability is significantly decreased for CuHA0.7 that contains the highest amount of copper (Fig. 7a). For the two highest copper amounts, a few cells, positive to calcein, present a reduced surface area and a particular morphology of their nuclei indicating that they have likely entered a process of apoptotic cell death (Fig. 7c, see arrows on lower panel). Nevertheless, even at 5 days, the viability rates remain close to $100 \%$ in all of the cases (Fig. 7a). Therefore, copper seems to have only a light negative influence on the cell physiology at this time. For all the time points, no necrotic cells are observed, regardless of the ceramic chemical composition. The CuHAx ceramics do not cause sudden cell death.

a)

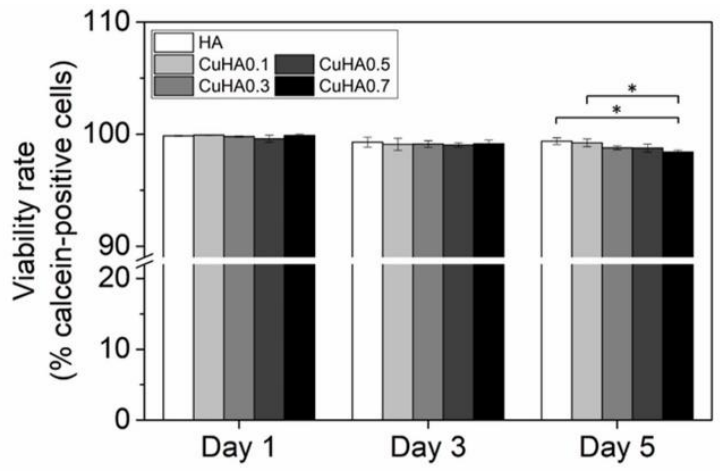

b)

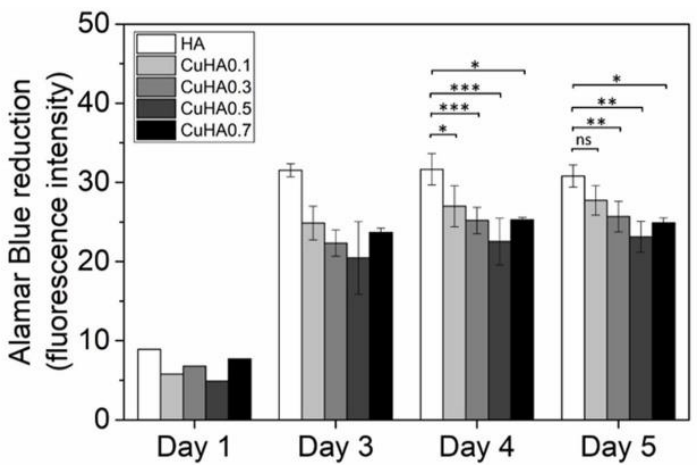

c)
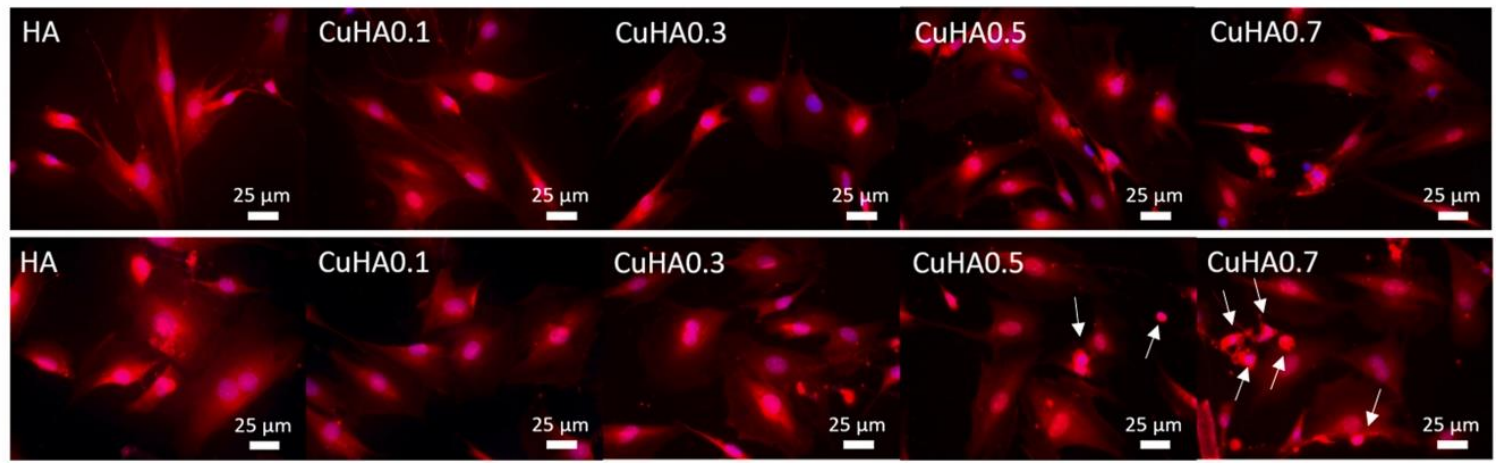

Fig. 7. The viability rate at the ceramic material surface (a) and the metabolic activity of the cell population over time (b). Statistical analysis: ANOVA-One way followed by Tukey post-hoc test: ns: non significant; *: $p<0.05 ;{ }^{* *}: p \leq 0.01$; $^{* * *}$ : $p \leq 0.0001$. Morphology of the viable cells observed in fluorescence microscopy after staining with calcein red-orange (in red); the nuclei were stained with Hoescht 33342 (in blue) after 3 days (upper panel) and 5 days (lower panel) of culture, arrows indicate cells presenting apoptotic morphology (c). (For interpretation of the references to colour in this figure legend, the reader is referred to the Web version of this article.)

The metabolic activity of the cells increases before becoming constant after 3 days (Fig. 7b). However, a significantly lower cell growth is observed on CuHAx ceramics in comparison with HA. On the fluorescence microscopy images (Fig. 7c), the confluence was not reached, which cannot explain this lower cell growth. The same behaviour is observed for all CuHAx ceramics up to 5 days whatever the copper amount may be. As the cell density remains similar on the HA and CuHAx samples (Figure A6), it can be stated that copper does not affect cell proliferation but cell activity. The alteration of cell functionality in presence of copper could be linked 
to the generation of reactive oxygen species [51]. Nevertheless, the cell activity on CuHAx is always more than $75 \%$ that of pure HA (used as a biocompatible material of reference), which is above the cytotoxicity threshold fixed at 70\% by the ISO standard 10993-5 [52]. In light of these results, the copper-substituted HA ceramics are non-cytotoxic after 5 days of culture.

To deepen this biological evaluation, the ability of the pre-osteoblastic cells to differentiate on the surface of the ceramics was evaluated through the detection of protein markers associated with osteogenesis by westernblot (Fig. 8). The evaluated proteins were the master transcription factor RUNX2 (Runt-related transcription factor 2), expressed early in the differentiation process, and osteopontin (OPN), a bone extracellular matrix protein associated to the mineralization process, expressed later. The expression of RUNX2 (Fig. 8b) is significantly lower when cells grew up on the ceramic materials than on the plastic in DM. In addition, RUNX2 expression tends to be reduced with the increasing amount of copper. But, it becomes significantly lower when compared to cells grown on HA only for CuHA0.7.

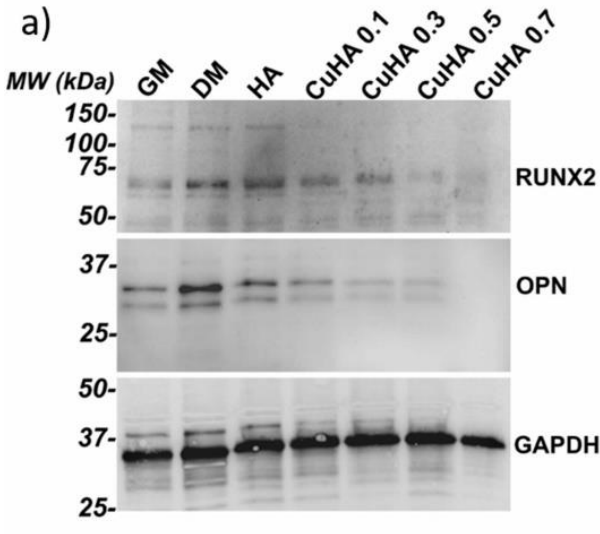

b)
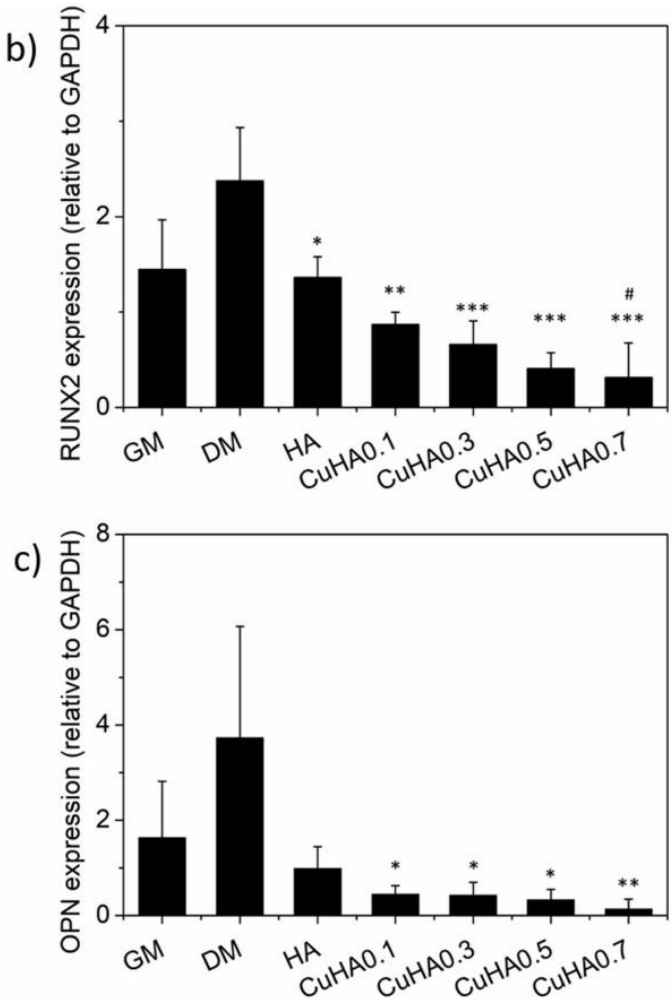

Fig. 8. Western-blot evaluation of the expression of RUNX2 and OPN in MC3T3-E1 cells (a). Semi-quantitative evaluation of the expression of RUNX-2 (b) and OPN (c) by densitometry analysis of the western-blot results. The values were normalized on GAPDH signal. Statistical analysis: ANOVA one way followed by a Tukey post hoc test. *: vs. DM, $p \leq 0.05$; ** vs. DM, $p \leq 0.01$; **: vs. DM, $p \leq 0.001 ; \#$ : vs. HA, $p \leq 0.05$.

In light of the expression profile of RUNX2 during osteogenesis, two hypotheses can be formulated. The osteogenic process is inhibited by the presence of copper in HA, or, conversely, differentiation is accelerated. Indeed, the cells used in this study are the subclone 14 derived from MC3T3-E1 pre-osteoblasts and selected for their capacity to differentiate easily. At the chosen time point, it is possible that the peak of expression associated with the initiation of osteogenesis may have already passed for the cells on the samples with higher copper content and still in progress for the cells on the plastic in DM. The reduction of RUNX2 for cells cultured on ceramics compared to cells on plastic in osteogenic culture medium was previously observed [12] and attributed to the second hypothesis.

The analysis of osteopontin expression levels (Fig. 8c) show no significant change when cells grown on plastic are compared according to the culture medium: GM or DM or on pure HA ceramics in DM. When cells were cultured on CuHA ceramics, the expression of OPN is significantly lower than that of cells on plastic in DM 
(positive control of differentiation) and is decreased comparatively to pure HA for the condition CuHA0.7. The visual observation of the cells during the experiment did not show any sign of a mineralization process. Therefore, the second hypothesis formulated above should likely be rejected. All together the osteoblastic differentiation-associated protein expression results suggest a negative effect of copper on pre-osteoblast differentiation in vitro when the copper amount in ceramics reaches $0.7 \mathrm{~mol}$ ( $5.3 \mathrm{wt} \%)$. At this step, an extensive biological study of cell behaviour including both osteoblastic and endothelial cells is needed for a wider understanding of the influence of copper substitution in HA. To make it possible, the precise control of the ceramic composition and purity is a prerequisite. As shown in this study, this can be achieved using an adjusted processing route to prevent copper segregation and the formation of secondary crystalline phase.

\section{Conclusion}

Calcium phosphate hydroxyapatite and copper oxide react at temperature close to $1000{ }^{\circ} \mathrm{C}$ to form coppersubstituted HA. This temperature is in the same range as that necessary to sinter the material. Thus, pure and dense copper-substituted HA ceramics containing up to $5.3 \mathrm{wt} \%$ of copper can by produced by solid-state reaction sintering at $1100^{\circ} \mathrm{C}$. Using these conditions, fine microstructures with submicronic CuHAx grains are obtained. Due to copper reduction during heating, copper with a mixed valence (and predominantly $\mathrm{Cu}^{\prime}$ ) substitutes for hydrogen into the hexagonal channels of the apatite lattice leading to a solid solution $\mathrm{Ca}_{10}\left(\mathrm{PO}_{4}\right)_{6} \mathrm{Cu}_{x}{ }_{x} \mathrm{Cu}_{y}^{\prime} \mathrm{O}_{2} \mathrm{H}_{2-2 x-y}$. The temperature dependant solubility of copper in the HA lattice can induce CuHA phase demixion and formation of $\mathrm{CuO}$ during cooling to room temperature. A quenching of the material can be performed to prevent this formation. The biocompatibility of the CuHAx ceramics towards the MC3T3-E1 cell line was assessed after 5 days of culture for ceramics containing up to $3.8 \mathrm{wt} \%$ of copper (CuHA0.5), the cell viability decreasing lightly above this amount. Nevertheless, a detrimental effect on cell growth was observed in the presence of copper at any amount in the HA. From these results, the biological behaviour of these bioceramics will be thoroughly investigated using more advanced biological models including primary osteogenic progenitors and endothelial cells.

\section{Declaration of competing interest}

The authors declare that they have no known competing financial interests or personal relationships that could have appeared to influence the work reported in this paper.

\section{Acknowledgements}

The authors thanks to the French regional council of Nouvelle Aquitaine for the financial funding given to this study. This work was also supported by institutional grants from the National Research Agency under the Investments for the future program with the reference ANR-10-LABX-0074-01 Sigma-LIM.

\section{Appendix A. Supplementary data}

The following is the Supplementary data to this article: Download : Download Word document (813KB) Multimedia component 1.

\section{References}

1. L.L. Hench. Bioceramics: from concept to clinic. J. Am. Ceram. Soc., 74 (1991), pp. 1487-1510, 10.1111/i.11512916.1991.tb07132.x

2. R.Z. LeGeros. Properties of osteoconductive biomaterials: calcium phosphates: Clin. Orthop., 395 (2002), pp. 81-98, 10.1097/00003086-200202000-00009

3. M.P. Ginebra, T. Traykova, J.A. Planell. Calcium phosphate cements as bone drug delivery systems: a review. J. Contr. Release, 113 (2006), pp. 102-110, 10.1016/i.jconrel.2006.04.007 
4. L. Sun, C.C. Berndt, K.A. Gross, A. Kucuk. Material fundamentals and clinical performance of plasma-sprayed hydroxyapatite coatings: a review. J. Biomed. Mater. Res., 58 (2001), pp. 570-592, 10.1002/jbm.1056

5. U. Heise, J.F. Osborn, F. Duwe. Hydroxyapatite ceramic as a bone substitute. Int. Orthop., 14 (1990), $\underline{10.1007 / B F 00178768}$

6. V. Karageorgiou, D. Kaplan. Porosity of 3D biomaterial scaffolds and osteogenesis. Biomaterials, 26 (2005), pp. 5474-5491, 10.1016/j.biomaterials.2005.02.002

7. H. Petite, V. Viateau, W. Bensaïd, A. Meunier, C. de Pollak, M. Bourguignon, K. Oudina, L. Sedel, G. Guillemin. Tissue-engineered bone regeneration. Nat. Biotechnol., 18 (2000), pp. 959-963, 10.1038/79449

8. J.C. Reichert, A. Cipitria, D.R. Epari, S. Saifzadeh, P. Krishnakanth, A. Berner, M.A. Woodruff, H. Schell, M. Mehta, M.A. Schuetz, G.N. Duda, D.W. Hutmacher. A tissue engineering solution for segmental defect regeneration in load-bearing long bones. Sci. Transl. Med., 4 (2012), 10.1126/scitransImed.3003720

9. D. Marchat, E. Champion. Ceramic devices for bone regeneration. Adv. Ceram. Biomater., Elsevier (2017), pp. 279-311

10. G. Daculsi, J.-M. Bouler, R.Z. LeGeros. Adaptive crystal formation in normal and pathological calcifications in synthetic calcium phosphate and related biomaterials. Int. Rev. Cytol., Elsevier (1997), pp. 129-191

11. S. Bose, G. Fielding, S. Tarafder, A. Bandyopadhyay. Understanding of dopant-induced osteogenesis and angiogenesis in calcium phosphate ceramics. Trends Biotechnol., 31 (2013), pp. 594-605, 10.1016/j.tibtech.2013.06.005

12. M.-M. Germaini, R. Detsch, A. Grünewald, A. Magnaudeix, F. Lalloue, A.R. Boccaccini, E. Champion. Osteoblast and osteoclast responses to $A / B$ type carbonate-substituted hydroxyapatite ceramics for bone regeneration. Biomed. Mater., 12 (2017), Article 035008, 10.1088/1748-605X/aa69c3

13. J.T.B. Ratnayake, M. Mucalo, G.J. Dias. Substituted hydroxyapatites for bone regeneration: a review of current trends: substituted HA for Bone Regeneration. J. Biomed. Mater. Res. B Appl. Biomater., 105 (2017), pp. 12851299, 10.1002/ibm.b.33651

14. E.S. Thian, T. Konishi, Y. Kawanobe, P.N. Lim, C. Choong, B. Ho, M. Aizawa. Zinc-substituted hydroxyapatite: a biomaterial with enhanced bioactivity and antibacterial properties. J. Mater. Sci. Mater. Med., 24 (2013), pp. 437-445, 10.1007/s10856-012-4817-x

15. L. Stipniece, K. Salma-Ancane, N. Borodajenko, M. Sokolova, D. Jakovlevs, L. Berzina-Cimdina. Characterization of Mg-substituted hydroxyapatite synthesized by wet chemical method. Ceram. Int., 40 (2014), pp. 3261-3267, 10.1016/j.ceramint.2013.09.110

16. W.L. Suchanek, K. Byrappa, P. Shuk, R.E. Riman, V.F. Janas, K.S. TenHuisen. Preparation of magnesiumsubstituted hydroxyapatite powders by the mechanochemical-hydrothermal method. Biomaterials, 25 (2004), pp. 4647-4657, 10.1016/i.biomaterials.2003.12.008

17. F. Ren, Y. Leng, R. Xin, X. Ge. Synthesis, characterization and ab initio simulation of magnesium-substituted hydroxyapatite. Acta Biomater., 6 (2010), pp. 2787-2796, 10.1016/j.actbio.2009.12.044

18. L. Veselinović, L. Karanović, Z. Stojanović, I. Bračko, S. Marković, N. Ignjatović, D. Uskoković. Crystal structure of cobalt-substituted calcium hydroxyapatite nanopowders prepared by hydrothermal processing. J. Appl. Crystallogr., 43 (2010), pp. 320-327, 10.1107/S0021889809051395

19. E. Kramer, E. Itzkowitz, M. Wei. Synthesis and characterization of cobalt-substituted hydroxyapatite powders. Ceram. Int., 40 (2014), pp. 13471-13480, 10.1016/i.ceramint.2014.05.072

20. M.A. Zykin, K.A. Babeshkin, O.V. Magdysyuk, E.O. Anokhin, W. Schnelle, C. Felser, M. Jansen, P.E. Kazin. Slow spin relaxation in dioxocobaltate(II) anions embedded in the lattice of calcium hydroxyapatite. Inorg. Chem., 56 (2017), pp. 14077-14083, 10.1021/acs.inorgchem.7b02237

21. A.S. Karpov, J. Nuss, M. Jansen, P.E. Kazin, Y.D. Tretyakov. Synthesis, crystal structure and properties of calcium and barium hydroxyapatites containing copper ions in hexagonal channels. Solid State Sci., 5 (2003), pp. 1277$1283, \underline{10.1016 / S 1293-2558(03) 00152-3}$

22. T. Baikie, G.M.H. Ng, S. Madhavi, S.S. Pramana, K. Blake, M. Elcombe, T.J. White. The crystal chemistry of the alkaline-earth apatites $\mathrm{A}_{10}\left(\mathrm{PO}_{4}\right)_{6} \mathrm{Cu}_{\mathrm{x}} \mathrm{O}_{\mathrm{y}}(\mathrm{H})_{\mathbf{z}}(\mathrm{A}=\mathrm{Ca}$, Sr and Ba). Dalton Trans. (2009), pp. 6722-6726, $\underline{10.1039 / B 906639 J}$

23. F. E Imrie, J.M. Skakle. Preparation of copper-doped hydroxyapatite with varying $\mathbf{x}$ in the composition $\mathrm{Ca}_{10}\left(\mathrm{PO}_{4}\right)_{6} \mathrm{Cu}_{\mathrm{x}} \mathrm{O}_{\mathrm{y}} \mathrm{H}_{\mathbf{z}}$. Bioceram. Dev. Appl., 3 (2013), 10.4172/2090-5025.S1-005 
24. S. Kato, T. Endo, M. Ogasawara. Reversible incorporation/deposition behavior of Cu on hydroxyapatites by heat treatment at elevated temperatures. Chem. Lett., 44 (2015), pp. 1518-1520, 10.1246/cl.150712

25. E.A. Abou Neel, I. Ahmed, J. Pratten, S.N. Nazhat, J.C. Knowles. Characterisation of antibacterial copper releasing degradable phosphate glass fibres. Biomaterials, 26 (2005), pp. 2247-2254,

10.1016/j.biomaterials.2004.07.024

26. C. Wu, Y. Zhou, M. Xu, P. Han, L. Chen, J. Chang, Y. Xiao. Copper-containing mesoporous bioactive glass scaffolds with multifunctional properties of angiogenesis capacity, osteostimulation and antibacterial activity. Biomaterials, 34 (2013), pp. 422-433, 10.1016/j.biomaterials.2012.09.066

27. B. Sutter, D.W. Ming, A. Clearfield, L.R. Hossner. Mineralogical and chemical characterization of iron-, manganese-, and copper-containing synthetic hydroxyapatites. Soil Sci. Soc. Am. J., 67 (2003), p. 1935, $10.2136 /$ sssaj2003.1935

28. V. Stanić, S. Dimitrijević, J. Antić-Stanković, M. Mitrić, B. Jokić, I.B. Plećaš, S. Raičević. Synthesis, characterization and antimicrobial activity of copper and zinc-doped hydroxyapatite nanopowders. Appl. Surf. Sci., 256 (2010), pp. 6083-6089, 10.1016/i.apsusc.2010.03.124

29. C. Moseke, M. Gelinsky, J. Groll, U. Gbureck. Chemical characterization of hydroxyapatite obtained by wet chemistry in the presence of V, Co, and Cu ions. Mater. Sci. Eng. C, 33 (2013), pp. 1654-1661,

10.1016/j.msec.2012.12.075

30. S. Shanmugam, B. Gopal. Copper substituted hydroxyapatite and fluorapatite: synthesis, characterization and antimicrobial properties. Ceram. Int., 40 (2014), pp. 15655-15662, 10.1016/j.ceramint.2014.07.086

31. M. Othmani, H. Bachoua, Y. Ghandour, A. Aissa, M. Debbabi. Synthesis, characterization and catalytic properties of copper-substituted hydroxyapatite nanocrystals. Mater. Res. Bull., 97 (2018), pp. 560-566, 10.1016/i.materresbull.2017.09.056

32. P.E. Kazin, M.A. Zykin, YuD. Tret'yakov, M. Jansen. Synthesis and properties of colored copper-containing apatites of composition $\mathrm{Ca}_{5}\left(\mathrm{PO}_{4}\right)_{3} \mathrm{Cu}_{\mathrm{y}} \mathrm{O}_{\mathrm{y}}+\delta(\mathrm{OH})_{0.5-\mathrm{y}-\delta} \mathrm{X}_{0.5}(\mathrm{X}=\mathrm{OH}, \mathrm{F}, \mathrm{Cl})$. Russ. J. Inorg. Chem., 53 (2008), pp. 362-366, 10.1134/S0036023608030042

33. S. Gomes, C. Vichery, S. Descamps, H. Martinez, A. Kaur, A. Jacobs, J.-M. Nedelec, G. Renaudin. Cu-doping of calcium phosphate bioceramics: from mechanism to the control of cytotoxicity. Acta Biomater., 65 (2018), pp. 462-474, 10.1016/j.actbio.2017.10.028

34. M.A. Zykin, A.V. Vasiliev, L.A. Trusov, R.E. Dinnebier, M. Jansen, P.E. Kazin. Solid state solubility of copper oxides in hydroxyapatite. J. Solid State Chem., 262 (2018), pp. 38-43, 10.1016/j.jssc.2018.03.003

35. L. Gaetke. Copper toxicity, oxidative stress, and antioxidant nutrients. Toxicology, 189 (2003), pp. 147-163, 10.1016/S0300-483X(03)00159-8

36. H. Tapiero, D.M. Townsend, K.D. Tew. Trace elements in human physiology and pathology. Copper, Biomed. Pharmacother., 57 (2003), pp. 386-398, 10.1016/S0753-3322(03)00012-X

37. Y. Li, J. Ho, C.P. Ooi. Antibacterial efficacy and cytotoxicity studies of copper (II) and titanium (IV) substituted hydroxyapatite nanoparticles. Mater. Sci. Eng. C, 30 (2010), pp. 1137-1144, 10.1016/i.msec.2010.06.011

38. S. Raynaud, E. Champion, D. Bernache-Assollant, P. Thomas. Calcium phosphate apatites with variable $\mathrm{Ca} / \mathrm{P}$ atomic ratio I. Synthesis, characterisation and thermal stability of powders. Biomaterials, 23 (2002), pp. 1065$1072,10.1016 / \mathrm{S} 0142-9612(01) 00218-6$

39. ISO 13779-3. Implants for surgery-hydroxyapatite-Part 3: chemical analysis and characterization of crystallinity and phase purity. Available online : https://www.sis.se/api/document/preview/80008203/ (2018)

40. S.M.J. Morse, G. Shaw, S.F. Larner. Concurrent mRNA and protein extraction from the same experimental sample using a commercially available column-based RNA preparation kit. Biotechniques, 40 (2006), pp. 54$58, \underline{10.2144 / 000112100}$

41. O. Hammer, D.A.T. Harper, P.D. Ryan, PAST: Paleontological Statistics Software Package for Education and Data Analysis, (n.d.) vol. 9.

42. C.-J. Liao, F.-H. Lin, K.-S. Chen, J.-S. Sun. Thermal decomposition and reconstitution of hydroxyapatite in air atmosphere. Biomaterials, 20 (1999), pp. 1807-1813, 10.1016/S0142-9612(99)00076-9

43. I. Rehman, W. Bonfield. Characterization of hydroxyapatite and carbonated apatite by photo acoustic FTIR spectroscopy. J. Mater. Sci. Mater. Med., 8 (1997), pp. 1-4, 10.1023/A:1018570213546 
44. P.E. Kazin, A.S. Karpov, M. Jansen, J. Nuss, Y.D. Tretyakov. Crystal structure and properties of strontium phosphate apatite with oxocuprate ions in hexagonal channels. Z. Anorg. Allg. Chem., 629 (2003), pp. 344-352, 10.1002/zaac.200390055

45. C. Henrist, K. Traina, C. Hubert, G. Toussaint, A. Rulmont, R. Cloots. Study of the morphology of copper hydroxynitrate nanoplatelets obtained by controlled double jet precipitation and urea hydrolysis. J. Cryst. Growth, 254 (2003), pp. 176-187, 10.1016/S0022-0248(03)01145-X

46. A. Stoch, J. Stoch, J. Gurbiel, M. Cichocińska, M. Mikołajczyk, M. Timler. FTIR study of copper patinas in the urban atmosphere. J. Mol. Struct., 596 (2001), pp. 201-206, 10.1016/S0022-2860(01)00718-9

47. S. Švarcová, M. Klementová, P. Bezdička, W. Łasocha, M. Dušek, D. Hradil. Synthesis and characterization of single crystals of the layered copper hydroxide acetate $\mathrm{Cu}_{2}(\mathrm{OH})_{3}\left(\mathrm{CH}_{3} \mathrm{COO}\right) \cdot \mathrm{H}_{2} \mathrm{O}$. Cryst. Res. Technol., $46(2011)$, pp. 1051-1057, 10.1002/crat.201100262

48. T. Bazin. Synthèse, caractérisations structurales par spectroscopie et mise en forme d'hydroxyapatites dopées au cuivre ou au fer (Synthesis, structural characterisation by spectroscopy and processing of copper or irondoped hydroxyapatites), PhD thesis. University of Bordeaux, France (2020)

49. J. Li, M.A. Subramanian, H.D. Rosenfeld, C.Y. Jones, B.H. Toby, A.W. Sleight. Clues to the giant dielectric constant of $\mathrm{CaCu}_{3} \mathrm{Ti}_{4} \mathrm{O}_{12}$ in the defect structure of " $\mathrm{SrCu}_{3} \mathrm{Ti}_{4} \mathrm{O}_{12}$. Chem. Mater., 16 (2004), pp. 5223-5225, $\underline{10.1021 / \mathrm{cm} 048345 \mathrm{u}}$

50. T.-T. Fang, H.-K. Shiau. Mechanism for developing the boundary barrier layers of $\mathrm{CaCu}_{3} \mathrm{Ti}_{4} \mathrm{O}_{12}$. J. Am. Ceram. Soc., 87 (2005), pp. 2072-2079, 10.1111/j.1151-2916.2004.tb06362.x

51. C. Gérard, L.-J. Bordeleau, J. Barralet, C.J. Doillon. The stimulation of angiogenesis and collagen deposition by copper. Biomaterials, 31 (2010), pp. 824-831, 10.1016/j.biomaterials.2009.10.009

52. ISO standard 10993-5. Evaluation biologique des dispositifs médicaux - Partie 5. Essais concernant la cytotoxicité in vitro (2009), p. 34 